\title{
Preliminary observations on the mandibles of palaemonoid shrimp (Crustacea: Decapoda: Caridea: Palaemonoidea)
}

Christopher W Ashelby, Sammy De Grave, Magnus L Johnson

The mandibles of caridean shrimps have been widely studied in the taxonomy and functional biology of the group. Within the Palaemonoidea the mandibles reach a high level of structural diversity reflecting the diverse lifestyles within the superfamily. However, the majority of studies have been restricted to light microscopy, with the ultrastructure at finer levels poorly known. This study investigates the mandible of nine species belonging to six of the recognised families of the Palaemonoidea using SEM and analyses the results in a phylogenetic and dietary framework. The results of the study indicate that little phylogenetic information is conveyed by the structure of the mandible, but that its form is influenced by primary food sources of each species. With the exception of Anchistioides antiguensis, all species examined possessed cuticular structures at the distal end of the pars molaris (molar process). Five types of cuticular structures are recognised herein, each with a unique form, but variable in number, placement and arrangement. Each type is presumed to have a different function which is likewise related to diet. 
2 Preliminary observations on the mandibles of palaemonoid shrimp (Crustacea: Decapoda:

3 Caridea: Palaemonoidea)

4

5 By: Christopher W. Ashelby 1,3)*, Sammy De Grave ${ }^{2)}$ and Magnus L. Johnson ${ }^{3)}$

6

7 1) APEM Ltd., 7 Diamond Centre, Works Road, Letchworth Garden City, SG6 1LW, United Kingdom.

$8{ }^{2)}$ Oxford University Museum of Natural History, Parks Road, Oxford, OX1 3PW, United Kingdom.

9 3) CEMS, University of Hull, Scarborough Campus, Filey Road, Scarborough, YO11 3AZ, United

10 Kingdom.

11

$12 *$ *orresponding Author email: c.ashelby@apemltd.co.uk.

13 
Introduction

Decapod crustaceans display a wide variety of modified mouthparts that serve both mechanical and sensory functions and have attracted the attention of taxonomists, systematicists and functional

19 biologists for decades (e.g. Borradaile, 1917; Fujino \& Miyake, 1968; Roberts, 1968; Caine, 1975;

20 Coombs \& Allen, 1978; Schembri, 1982; Felgenhauer \& Abele, 1985; Garm \& Høeg, 2001; Garm, 21 Hallberg \& Høeg, 2003; Garm, 2004). The semi-rigid, robust mandible has usually been attributed a 22 solely mechanical function in the breaking down of food prior to ingestion, but a recent study of larval

23 Palaemon elegans Rathke, 1837 demonstrated that it possesses a variety of sensilla (Geiselbrecht \& 24 Melzer, 2013), suggesting that it may be more complex than previously thought. Indeed, Borradaile 25 (1917) in his pioneering work on the structure and function of the mouthparts of palaemonid prawns concluded that "the mandible of the Crustacea is an exceedingly complicated, varied and interesting organ, presenting many problems and worthy of a great deal more attention than it has received".

28 Nearly a century on and the caridean mandible, although superficially described in numerous taxonomic works, remains poorly studied at a structural level and very few studies have focussed on the detailed morphology and potential evolutionary drivers in relation to the form of the mandible.

31 Recent investigations have added to our knowledge of the mandible across a range of crustacean taxa 32 but have largely focussed on larvae (e.g. Heral \& Saudray, 1979; Casanova, De Jong \& Moreau, 2002;

33 Tziouveli, Bastos-Gomez \& Bellwood, 2011; Geiselbrecht \& Melzer, 2013) or are restricted to a single 34 or a small number of species within a single genus or family (e.g. Fujino \& Miyake, 1968; Caine, 35 1975; Coombs \& Allen, 1978; Mielke, 1984; Felgenhauer \& Abele, 1985; Hobbs, 1991; Moore, 36 Rainbow \& Larson, 1993; Richter, 2004; Arndt, Berge \& Brandt, 2005; Mekhanikova, 2010). Within 37 the Palaemonoidea, the two most extensive studies on mandibles focus on the genus Palaemon, using light microscopy to examine its structure and function (Borradaile, 1917 - as Leander) and interspecific variation (Fujino \& Miyake, 1968).

Within the infraorder Caridea, the mandible is variously developed (Burukovsky, 1986) but is frequently comprised of a pars incisivus (incisor process) and pars molaris (molar process) and may be provided with a palp or not. Both the pars incisivus and the pars molaris are variable in form ranging from truncated to elongate, straight to markedly curved, narrow to flared, widely separated to barely separated and many gradations in between (Burukovsky, 1986). The distal portions of both processes are often provided with acute or rounded lobes ('teeth') or ridges but may be flattened. Either the pars 
46 incisivus or the pars molaris may be reduced or absent or they may be fused together. Due to this

47 diversity in the development and form, features of the mandible have been used in the taxonomy of

48 caridean shrimps, particularly in families where few characters exist to differentiate genera and species,

49 such as in Palaemonidae. Additionally, several classifications of the Caridea have, in part, also been

50 underpinned by features of the mandible (Thompson, 1967; Christofferson, 1990; Chace, 1992).

In many decapods, mastication largely occurs in the gastric mill (Caine, 1975). Patwardhan

52 (1934) expressed an opinion that many carideans lack a complex gastric mill and thus the mouthparts

53 are correspondingly more developed, although more recent studies (e.g. Felgenhauer \& Abele, 1983)

54 demonstrate the presence of a gastric mill in a number of caridean families. Regardless, the mandible

55 is involved in the initial breakdown of food and therefore has a large functional significance and thus

56 its' form may provide insights into the diet or feeding mode of the species. Indeed, species that have

57 particular dietary regimes or feeding mechanisms tend to have correspondingly specialised mouthparts

58 (Caine, 1975). During feeding the pars incisivus is believed to be mostly used in cutting and slicing of

59 food particles into more manageable portions whilst the pars molaris is usually thought to have a

60 grinding function (Bauer, 2004), although Felgenhauer \& Abele (1985) found that the mandible of

61 atyid shrimps, that do possess a gastric mill, was not used for crushing food.

62 Whilst previous studies on shrimps have investigated mouthpart morphology of a single genus

63 or species (Borradaile, 1917; Fujino \& Miyake, 1968) or between genera belonging to the same family

64 (Felgenhauer \& Abele, 1985), only the study of Storch, Bluhm \& Arntz (2001) on three Antarctic

65 shrimps has used SEM to investigate differences across families. The present, SEM based, study was

66 conceived to investigate the ultrastructure of the mandible in nine species belonging to nine different

67 genera, across six out of seven families from the superfamily Palaemonoidea, thus covering a diversity

68 of form and ecology, to evaluate the potential phylogenetic significance within the superfamily and the

69 relationship between diet and structure.

71 Material and Methods

De Grave \& Fransen (2011) listed eight families included within the superfamily

74 Palaemonoidea with the Palaemonidae further split into two subfamilies: the Palaemoninae and the

75 Pontoniinae. However, the family Kakaducarididae has been recently synonymised with the

76 Palaemonidae (see Short, Humphrey \& Page, 2013) leaving seven valid families. Three of these 
77 families are monogeneric (Anchistioididae, Desmocarididae and Typhlocarididae) whilst the highest

78 diversity of both morphology and lifestyle is found in the subfamily Pontoniinae. No members of the

79 Typhlocarididae were available for destructive examination via SEM and references to the morphology

80 of the mandible in Typhlocaris are based on descriptions in the literature (Calman, 1909; Parisi, 1921;

81 Caroli, 1923; 1924; Tsurnamal, 2008). Despite several attempts to process left mandibles of

82 Euryrhynchus, none survived the sonication stage intact and therefore observations are based on the

83 right mandible only. All specimens studied are held in the Zoological Collection of the Oxford

84 University Museum of Natural History (OUMNH.ZC) with details included in Table 1.

85

86

87

88

89

90

91

92

93

94

95

96

97

98

99

100

101

102

103

104

105

106

107

The methods used for preparation of tissue follow those established by Martin, Liu \& Striley (2007) and De Grave \& Goulding (2011). Mandibles were carefully dissected from specimens stored in $75 \%$ ethanol. After removal mandibles were passed through a graded ethanol series to distilled water, subjected to brief (5-15 seconds) sonication using a light surfactant, then re-hydrated in graded ethanol to $100 \%$, with drying done via the HMDS (hexamethyldisilazane) method. Dried specimens were coated with a gold-palladium mixture in a Polaron E5000 coating unit and observed in a JEOL JSM-5510 microscope.

Terminology of the teeth on the pars molaris refers to their position in situ (see Fujino \& Miyake, 1968), with setal definitions following Garm (2004).

\section{Results}

Salient features of each mandible structure are outlined in Tables 2-5 and illustrated in Figs. 17; only comparative remarks are detailed below.

The most common form of mandible of those species studied is bipartite, with a well developed pars incisivus and pars molaris (Table 2). Only in Hymenocera picta Dana, 1852 (Tables 2 and 3; Fig. 4D) is the pars incisivus absent whilst in Gnathophyllum elegans (Risso, 1816) (Tables 2 and 3; Fig. $5 \mathrm{~A}$ ) it is reduced to a vestigial process. In all other species the structure of the pars incisivus is similar (Table 3) being flattened and provided with teeth distally. In Pontonia pinnophylax (Otto, 1821), a series of denticles is also present along the posterior margin (Table 3; Figs. 3A and 3C).

A mandibular palp is present only in Palaemon macrodactylus Rathbun, 1902 (Table 2) and Macrobrachium nipponense (De Haan, 1849) (Table 2; Fig. 2C). In both these species the structure of the palp is similar, being three segmented (but see Fujino \& Miyake, 1968 for discussion on variation 
108 in this character in P. macrodactylus), with the distal segment being more slender and slightly longer

109 than the basal and penultimate segments. Distally-serrulate setae are present (Fig. 1D) on all segments

110 of the palp but most numerous on the distal segment.

111 A great diversity of form is present in the pars molaris. In all species examined, the pars

112 molaris is well developed and ranges from rounded (P. macrodactylus, M. nipponense, Periclimenaeus

113 caraibicus Holthuis, 1951, H. picta), oval (G. elegans, Desmocaris bislineata Powell, 1977,

114 Euryrhynchus wrzesniowskii Miers, 1877), slightly squared (P. pinnophylax, Anchistioides antiguensis

115 (Schmitt, 1924) right) to roughly triangular (A. antiguensis left) in cross-section. Most are roughly

116 parallel sided but those of H. picta and G. elegans are strongly curved, that of D. bislineata has convex

117 lateral margins and in $A$. antiguensis the pars molaris is strongly flared distally. Teeth are present

118 distally on most mandibles (Palaemon, Figs. 1A and 1E; Macrobrachium, Figs. 2A and 2C-D;

119 Pontonia, Figs. 3B and 3D; Anchistioides, Figs. 7D-F; Hymenocera, Figs. 4E-F; Gnathophyllum, Fig.

120 5D), whilst in others these are fused to form lip-like structures (Euryrhynchus, Figs. 7A-B;

121 Periclimenaeus, Figs. 4A-C) and in Desmocaris no teeth are present and the distal end is a ridged plate

122 (Figs. 6A-B and 6D-F). The form of the teeth is highly variable with spine-like teeth being present in

123 Hymenocera (Figs. 4E-F), a blade like tooth being present in Gnathophyllum (Fig. 5D) and more lobate

124 teeth present in the other species. The lobate teeth may be reduced to low mounds or massively

125 produced with the tips entire or bifid as well as all gradations in between. Significant differences in the

126 arrangement and structure of the teeth are also noted between the left and right mandibles. Typically

127 four teeth are present although in some species these are modified such that they are difficult to

128 discern.

129 In addition to the teeth and cusps mentioned above, the distal end of the pars molaris of most

130 mandibles examined here were found to be covered, to a greater or lesser degree, by numerous

131 filamentous structures, which are flexible to semi-rigid and frequently developed into rows (Figs. 1B-

$132 \mathrm{C}, 1 \mathrm{~F}, 2 \mathrm{~A}-\mathrm{B}, 3 \mathrm{E}, 3 \mathrm{~F}, 4 \mathrm{~B}-\mathrm{C}, 4 \mathrm{E}-\mathrm{F}, 5 \mathrm{~A}-\mathrm{D}, 6 \mathrm{~A}-\mathrm{F}$ and 7A-C). The individual filaments do not conform to

133 any described form of seta nor to the definitions of setae in Watling (1989) or Garm (2004), in

134 particular lacking a complete basal articulation and a continuous lumen. The arrangement, placement

135 and ultra-structure of these cuticular structures (CS) is highly variable, but can be broadly classified

136 into five types.

137 Type I CS are semi rigid, parallel sided or slightly tapered distally and between 40 and $60 \mu \mathrm{m}$

138 long and 3-6 $\mu \mathrm{m}$ wide and tend to form rows. They are found in Palaemon (Figs. 1B-C and 1F), 
139 Macrobrachium (Figs. 2A-B and 2D), Pontonia (Figs. 3B and 3D-F) and Euryrhynchus (Figs. 7A-C).

140 In Euryrhynchus shorter structures are also present (Fig. 7C), but these appear structurally similar to

141 Type I and are herein regarded as the same type.

142 Type II CS are found only in Periclimenaeus. These appear more rigid and slightly stouter than

143 Type I structures and form tufts rather than rows (Figs. 4B-C).

144 Type III CS are found in Gnathophyllum. They are approximately $60 \mu \mathrm{m}$ long and $5 \mu \mathrm{m}$ wide,

145 highly flexible, taper strongly distally with a "feathered" inner margin and have a weak constriction

146 basally (Figs. 5A-D). They form a dense covering over the entirety of the distal end of the pars

147 molaris.

148 Type IV CS (Figs. 4E-F) are very similar to Type III differing chiefly in lacking a feathered 149 inner margin and a weak basal constriction. They are exclusively found in Hymenocera.

150 Type V CS are unique to Desmocaris and are the most highly modified. They comprise about

15112 finger-like projections arising from a basal column (Figs. 6B-D and 6F).

152 The details of the positioning and arrangement of the cuticular structures are presented in Table

1535 and the figures referred to therein. No cuticular structures were observed on the mandibles of

154 Anchistioides antiguensis.

155 These cuticular structures have been noted in several light microscopy studies or taxonomic

156 descriptions (e.g. Borradaile, 1917; Fujino \& Miyake, 1968; Felgenhauer \& Abele, 1985; Storch,

157 Bluhm \& Arntz, 2001; Fransen, 2006), where the elements have typically been referred to as setae or

158 bristles, but no detailed study of these features has been conducted to date. In some species setules are

159 also present on the disto-lateral margins (Figs. 4F, 6B-C and 6E-F).

160

161 Discussion

162

163

164 living species to obligate, or loose, associations with a variety of other invertebrates including

165 cnidarians, sponges, echinoderms, molluses and ascidians. The diversity of lifestyles and feeding

166 strategies within palaemonoid shrimps has resulted in a large range of morphological adaptations,

167 including the mouthparts and they therefore provide an ideal model group to propose hypotheses

168 related to the evolution of these structures. The hypotheses addressed here were that the structure of 
169 the mandible should convey information on the species' diet and/or may potentially shed light on the 170 phylogenetic relationships of the taxa.

171 Whilst there is considerable variation in the mandible of palaemonoid shrimps noted in the 172 literature, the most common form of mandible across the superfamily is with both a well-developed 173 pars inscisivus and pars molaris, with a mandibular palp being absent more often than present.

174 When present, the pars incisivus is of fairly constant form, differing only in its robustness and 175 the number of distal teeth, this latter character often being also variable between the left and right 176 mandibles. The pars incisivus of Pontonia is the most unusual of those investigated here in bearing a 177 row of small denticles on the posterior border. These denticles are also present in most species of the 178 closely related genera Ascidonia, Dactylonia, Odontonia but not in Bruceonia (see Fransen, 2002) but 179 are not described in any other palaemonoid shrimp.

180 The gross morphology of the pars molaris is far more variable between genera than a review of 181 the literature would suggest. This may be partly due to oversights in descriptions or because frequently 182 only one mandible is described and illustrated or simply the limitations of light microscopy. The right 183 and left pars molaris in most cases showed significant differences in structure and are often configured 184 such that there is a rough interlocking between the two sides when closed as also noted by Borradaile 185 (1917). More startling is the wide degree of variation and intricacies in design of the cuticular structures. As mentioned, the presence of 'setae' or 'bristles' on the pars molaris has been noted in previous studies. However, these cursory mentions do not hint at the diversity in form, placement and arrangement witnessed in comparatively few species examined here.

\section{Types of mandible and their presumptive function}

197 Type A mandible: Well developed pars incisivus and pars molaris; pars molaris distally cuspidate; 198 with Type I CS; encountered in Palaemon macrodactylus, Macrobrachium nipponense, Euryrhynchus 199 wrzesniowskii and Pontonia pinnophylax (Figs. 1, 2, 3 \& 7A-C). 
Palaemon macrodactylus is largely carnivorous with a preference for mysid and amphipod crustaceans (Sitts \& Knight, 1979; Siegfried, 1982; González-Ortegón et al., 2010; Ashelby, unpublished data). The specific, natural diet of Macrobrachium nipponense has not been studied but it is likely that, as with most Macrobrachium, it is omnivorous with a tendency towards carnivory (Jayachandran \& Joseph, 1989; Mantel \& Dudgeon, 2004; Short, 2004). The diet of the congeneric $M$.

205

206 hainanense (Parisi, 1919) is dominated by insect larvae and gastropod molluscs (Mantel \& Dudgeon, 2004) and a similar diet may be assumed for M. nipponense. Although the diet of Euryrhynchus wrzesniowskii has not been studied, Kensley \& Walker (1982) provide some information on the diet of the related E. amazoniensis Tiefenbacher, 1978, whilst Walker (2009) also gave information on the diet of this species and E. burchelli Calman, 1907. Both species feed on a diverse prey range and can be regarded as omnivorous with a preference for live insect larvae. The diet of Pontonia pinnophylax is unclear. Pontonia inhabit lamellibranch bivalve, gastropod or ascidian hosts (Fransen, 2002; Marin \& Anker, 2008). Richardson et al. (1997) concluded that the most likely food sources of $P$. pinnophylax were pseudofaeces (mucous-bound suspended particles rejected as food by the bivalve) or material collecting in the mantle cavity. Similarly, Aucoin \& Himmelman (2010) observed Pontonia mexicana Guérin-Méneville, 1855 feeding on matter in mucus strings. Gut content analysis has revealed the presence of detrital material, plant material and crustacean exuviae (Richardson et al., 1997). Finally, Kennedy et al. (2001) concluded that Pontonia assimilated similar food to their bivalve hosts based on similar stable isotope carbon measurements.

The hard-bodied, relatively large prey consumed by Palaemon, Macrobrachium and Euryrhynchus would require breaking down prior to ingestion. This suggests the requirement for a grinding mandible and the application of force. The cuspidate nature of the pars molaris of the Type A mandible is supportive of such a grinding function. The abraded nature of many of the cuticular structures (particularly evident in Figs. 1B-C) also supports this view. It would also be necessary for the shrimp to sense the prey between the mandibles to know what force is being applied to the prey, when the prey had been ground enough to ingest or when exoskeletons or shells of the prey had been broken. This is the presumed function of the Type I CS in the Type A mandible. Type I CS are most similar to microtrichia, which are common in crustaceans, particularly in amphipods (e.g. Steele \& Oshel, 1987; Oshel, Steel \& Steel, 1988; Olyslager \& Williams, 1993; Wong \& Williams, 2009; Zimmer, Araujo \& Bond-Buckup, 2009; Mekhanikova et al., 2012) and have also been noted in larval decapods (e.g. Pohle \& Telford, 1981; Tziouveli, Bastos-Gomez \& Bellwood, 2011). Typically 
231 microtrichia are thought to have a sensory function (Olyslager \& Williams, 1993; Wong \& Williams,

232 2009) and usually arise from a socket and terminate in a pore. A socket and pore are not evident in the

233 images used here but this may be due to the abraded nature of many of the structures (see Figs. 1B-C).

234 It is not clear how the presumed diet of Pontonia links to this mandible type. Assuming a

235 pseudofaeces or mucus diet is correct, there would not be the same requirement for grinding or

236 mechanosensory structures. Similarly De Jong-Moreau, Casanova \& Casanova (2001) noted that

237 mandibular structure does not always reflect diet.

238 Based on examination of stomach content, Tsurnamel (2008) suggested that Typhlocaris

239 ayyaloni Tsurnamal, 2008 feeds on bacterial mats and some small crustaceans. Feeding on bacterial

240 mats may require specialised feeding structures; however, Figure 2F in Tsurnamel (2008) shows a

241 mandible of very similar appearance to that of Macrobrachium and Palaemon which instead suggests a

242 similar diet. This is further supported by the sensitivity of Typhlocaris to vibration (Tsurnamel, 2008)

243 which would aid in prey detection. This suggests that small crustaceans may form the greater

244 proportion of the diet of Typhlocaris. Whether cuticular structures are present is not evident from the

245 figures or descriptions in any Typhlocaris species.

247 Type B mandible: Well developed pars incisivus and pars molaris; pars molaris distally cuspidate;

248 lacking cuticular structures; only encountered in Anchistioides antiguensis (Figs. 7D-F). It differs from

249 the Type A mandible chiefly through the lack of cuticular structures. The pars molaris is also distally

250 flared which is one of the defining characteristics of the family Anchistioididae.

The known species of Anchistioides are commonly associated with of a variety of shallow

252 water sponges, inhabiting the oscula. It may be speculated that they feed either on detritus collected

253 within the osculum of the sponge, other organisms associated with the sponge, the sponge itself, or a

254 combination of these. The only evidence as to the diet of Anchistioides was provided by Wheeler \&

255 Brown (1936) who report the presence of 'worm setae' in the stomachs of two specimens of $A$.

256 antiguensis. The lack of any sensory apparatus may support preying on softer bodies animals which

257 would require less force to break down.

258

259 Type C mandible: Well developed pars incisivus and pars molaris; pars molaris asymmetrical with 2

260 acute ridges on right and tricuspid on left; with Type II CS; only encountered in Periclimenaeus

261 caraibicus (Figs. 4A-C). There is a considerable degree of variation in the mouthparts of 
262 Periclimenaeus spp. reported in the literature and thus this type of mandible may not be standard for 263 the genus as a whole. In literature (see Holthuis, 1951; Holthuis, 1952 for examples) variation in the 264 development of the pars incisivus is noted as well as variation in the development or presence of 265 cuticular structures but this latter difference may again be attributable to oversight in the descriptions 266 and figures due to difficulties observing this feature under light microscopy. The ecological and 267 perhaps phylogenetic significance of variation in features of the mandible amongst Periclimenaeus 268 species warrants further investigation.

Duriš et al. (2011) report that Periclimenaeus caraibicus feeds on the host sponges, noting the presence of spicules in the stomach and that the shrimp takes on the colour of the host sponge through assimilation of the sponge's pigments. The form of the mandible witnessed here is also suggestive of a specialised diet. The multidentate, serrated form of the pars incisivus would aid in the shredding of sponge fragments, whilst the acute nature of the ridges of the right pars molaris may also aid in tearing. The sponge fragments may then be transferred into the groove of the right pars molaris into which the teeth of the left pars molaris can interlock to grind the sponge down. The groove may also help align unbroken spicules such that they enter the mouth in the correct orientation. The function and placement of the Type II CS in this mandible is difficult to explain. They appear similar in form to Type I CS and may therefore also be assumed to have a similar sensory function but their placement in discrete tufts may suggest a slightly different function. It is speculated that these tufts of cuticular structures are the vestiges of those found in Pontonia (see Figs. 3E-F) and that they only have limited 281 functionality.

Sponge feeding cannot be presumed to be a generalised diet for Periclimenaeus as some other members of this genus are associates of compound ascidians (Fransen, 2006) and so presumably have different feeding ecology which may be reflected in the form of their mandible, as discussed above.

Type D mandible: Pars incisivus strongly reduced to vestigial spine-like process; pars molaris with single blade-like tooth distally; with Type III CS; only encountered in Gnathophyllum elegans (Fig. 5). Type D mandibles are highly modified and display a number of unusual features, most notably the reduction of the pars incisivus and the dense covering of Type III CS.

Little information is available on the diet of Gnathophyllum. Both Wickler (1973) and Bruce 291 (1982) speculate that Gnathophyllum are predatory on echinoderms, however this hypothesis has not 292 been confirmed. However, the highly modified form of all their mouthparts is suggestive a specialised 293 food resource. During feeding, shrimps use the anterior mouthparts (maxillae and maxillipeds) to hold 
294 and manipulate food (Bauer, 2004). The operculate, calcified nature of the anterior mouthparts may 295 not be able to manipulate food in the same way as the more flexible mouthparts found in most of the 296 other genera examined here. The strongly reduced pars incisivus is suggestive that there is not a 297 requirement for tearing or shredding of food items and the lack of a grinding surface on the pars 298 molaris indicates that there is no requirement for breaking down food. Furthermore, the mandibles of 299 Gnathophyllum are exceedingly small in relation to the body size of the shrimp and would be unlikely 300 to be able to deal with large food items. Finally, the Type III CS appear highly flexible and cilia-like. 301 These various adaptations would suggest that rather than large food items, Gnathophyllum feed on 302 small particulate matter, mucus or fluids or perhaps echinoderm tube-feet and that the Type III CS are 303 involved in movement of these food resources.

304 Although some species of Gnathophyllidae are commensal with echinoderms (Bruce, 1982),

305 Gnathophyllum elegans is considered free living. However, Gnathophyllum spp. do seem to form

306 loose associations with echinoderms (S. De Grave, pers. obs.) and Bruce (1982) reports that $G$.

307 americanum Guérin-Méneville, 1855 has been observed using its outer maxillipeds to browse on the 308 extended papulae on the dorsal surface of asteroids. This, combined with the modifications to the 309 mandible further supports the idea that Gnathophyllum feed on mucus or mucus entrapped particles, as 310 has also been suggested by Bruce (1982) for some other echinoderm associates such as Zenopontonia 311 rex (Kemp, 1922) [as Periclimenes imperator Bruce, 1967], Lipkemenes lanipes (Kemp, 1922), Z.

312 soror (Nobili, 1904) and Periclimenes pectiniferus Holthuis, 1952.

314 Type E mandible: Pars incisivus absent; pars molaris bearing two recurved spine-like teeth distally; 315 with Type IV CS; encountered only in Hymenocera picta (Figs. 4D-F).

316 This type of mandible is differentiated from the Type D mandible through the complete absence 317 of the pars incisivus, the presence of two recurved teeth on each mandible rather than a single blade318 like tooth, and by the form and arrangement of the cuticular structures. As in the Type D mandible the 319 pars molaris lacks a grinding surface.

321 other mouthparts (a factor that has lead to their previous inclusion in a single family) that it would be 322 reasonable to assume a similar diet. However, Wickler (1973) noted that Hymenocera feed exclusively 323 on starfish, particularly Nardoa and Linkia spp. piercing the epidermis with their first pereiopods 324 before extracting internal tissues. 
The sparse arrangement of cuticular structures would also not be as effective at moving mucus or particles as those in the Type D mandible of Gnathophyllum. It seems likely, therefore, that the

327 Type E mandible is a further development of the Type D mandible in response to a dietary switch in

328 Hymenocera (or its ancestors) from merely removing mucus from the echinoderms to actually

329 predating on them. The paired teeth of the right pars molaris apparently interlink with those of the left

330 and may take on the slicing role normally attributed to the pars incisivus.

Type F mandible: Well developed pars incisivus and pars molaris; pars molaris distally flattened and ridged; with Type V CS; only encountered in Desmocaris bislineata.

Type V CS are the most highly developed of all the cuticular structures noted in this study. They in turn dictate the form of this mandible type as the finger-like projections together form the ridged surface of the pars molaris. They appear to be flexible and may be regarded as shorter versions of the cilia-like Type III CS. A particulate or detritivorous diet may therefore be expected. This is consistent with the information provided by Powell (1977) who states that "normal feeding activity involves exploration of the surface of dead leaves etc....most of the food probably consists of fine particles...captive shrimps recoil from contact with live animals such as naidid oligochaetes and chironomid larvae; however they eagerly consume dead ones and therefore do not seem to be restricted to microphagy'. Although a strong pars incisivus is present for initial tearing, the Type F mandible does not have obvious grinding function and it is unclear how these carrion prey items would be broken down prior to ingestion. Another possible function for the elaborate arrangement of cuticular structures in this mandible type is that they may help to filter particular matter.

\section{Systematic considerations}

The form of the mandible was considered by Thompson (1967) to be of significant importance in the phylogeny of the Caridea, with the ancestral state considered to be a fused pars molaris and pars incisivus, combined with a 3-segmented palp. Indeed, the recognition of several families, including some incorporated in this study, has partially been justified by the form of the mandible. The ridged nature of the pars molaris, which is presumed to be a primitive feature (Sollaud, 1911; Borradaile, 1917) is one of the characters used to define the family Desmocarididae (Borradaile, 1915; Powell, 1977) and the presence of a distally flared molar process of the mandible is one of the defining characteristics of the family Anchistioididae (Chace, 1992). However, Fransen \& De Grave (2009) 
357

358

359

360

361

362

363

364

365

366

367

368

369

370

371

372

373

374

375

376

377

378

379

380

381

382

383

384

385

386

387

concluded that whilst the form of mandible is of considerable value in the identification of carideans, its phylogenetic significance at the family level is uncertain. The inclusion of relatively few species in this study, encompassing less than $1 \%$ of palaemonoid diversity, albeit from the majority of palaemonoid families, will not uncover the complete range of forms of the mandible likely to be found in this group, meaning that the results of this study should be regarded as indicative rather than absolute. Furthermore, the analysis of a single character in isolation cannot hope to resolve systematic relationships, rather an integrative approach, including novel characters and possibly also molecular data is advised (Li et al., 2011). Nevertheless some preliminary observations on the structure of the mandible in relation to currently accepted phylogenies can be made.

The six mandibular types proposed here do not reflect currently accepted relationships within the Palaemonoidea. As many of the groupings are based on single taxa they may actually imply species specific differences or, perhaps reflect over-splitting of mandibular types in this study.

The genera Palaemon and Macrobrachium, both currently assigned to the Palaemoninae, have the same general structure of the mandible (Type A); however, the other genera with this form of mandible are more difficult to explain from a phylogenetic point of view. Pontonia shares a greater affinity to Gnathophyllum, Hymenocera and Periclimenaeus (Mitsuhashi et al., 2007; Bracken, De Grave \& Felder, 2009, Gan et al., 2015) than to Palaemon or Macrobrachium whilst Euryrhynchus, considered to be an ancient lineage (De Grave, 2007), represents a sister group to Desmocaris (see Bracken, De Grave \& Felder, 2009). Palaemon and Macrobrachium both also possess a mandibular palp. The traditional view of the mandibular palp is that the presence of a three segmented mandibular palp represents the primitive condition in Caridea (Thomson, 1967) with a reduction in the number of segments and subsequent loss in more derived lineages. However, the presence or absence of a mandibular palp has been demonstrated to convey very limited phylogenetic information and is not a consistent character in Palaemonidae, varying even within a species (Ashelby et al., 2012; De Grave \& Ashelby, 2013).

Although classified into two different mandible types here (Type D and Type E), the mandibles of Gnathophyllum and Hymenocera are linked through the reduction of the pars incisivus, a feature that is variable in the gnathophyllid genus Gnathophylloides (see Chace \& Bruce, 1993). Mitsuhashi et al. (2007), Bracken, De Grave \& Felder (2009) and Gan et al, 2015, based on a molecular phylogeny, demonstrated that Hymenoceridae and Gnathophyllidae represent a derived lineage within the Pontoniinae. The mouthparts present many of the definitive morphological characters of this lineage. 
388 The gradual reduction of the pars incisivus witnessed in the Gnathophyllidae and Hymenoceridae is 389 also a feature demonstrated in several Pontoniinae taxa indicating the potential plasticity of this 390 character within the subfamily. Reduction of the pars incisivus, although to a lesser degree, is also 391 evident in Figure 8A in Bruce \& Short (1993) of Calathaemon holthuisi (Strenth, 1976) (ex-

392 Kakaducarididae, now Palaemonidae). A gradual reduction of the pars incisivus at family level is 393 indicated by Burukovsky (1986) with Gnathophyllidae being intermediate in form between

394 Palaemonidae and Crangonidae. However, these latter families, and the Eugonatonotidae in which the 395 pars incisivus is also absent, are not closely related (Mitsuhashi et al., 2007; Bracken, De Grave \& 396 Felder, 2009; Li et al., 2011) suggesting that the loss of the pars incisivus has occurred independently 397 several times in the evolution of the Caridea.

398 This study has demonstrated that the form of the mandible is much more complex than 399 previously thought. The traditional view that the pars molaris is used solely for the grinding of food 400 seems a gross oversimplification and in some species (e.g. G. elegans, H. picta) the arrangement and 401 form of the teeth would suggest that it does not grind at all. The form and arrangement of cuticular 402 structures at the distal end of the pars molaris shows a particularly high degree of variation. The five 403 types of cuticular structures recognised in this study are presumed to have different functions related to 404 food sources, which is contrary to the findings of Storch, Bluhm \& Arntz (2001) who found no link 405 between the morphology of the mouthparts and food items.

406 Some evidence of evolutionary relationships is conveyed through the broad structure of the 407 mandible but the detailed structures witnessed in this study do not reflect the evolutionary relationships 408 in the Palaemonoidea suggested by previous phylogenetic reconstructions (Mitsuhashi et al., 2007; 409 Bracken, De Grave \& Felder, 2009; Li et al., 2011). This preliminary study thus suggests that the 410 structure of the mandible is more related to function in relation to diet, than evolutionary relationships.

411 With such a diversity of lifestyles represented by the Palaemonoidea, particularly within the subfamily 412 Pontoniinae, further studies including many other genera are however required to fully unravel the 413 diversity of mandible morphology within the superfamily.

\section{Acknowledgements}

416 
419 Unicomarine Ltd. partially supported the work of the first author. John Short and an anonymous

420 reviewer made useful comments and corrections.

421

422 References

423

424 Arndt CE, Berge J, Brandt A. 2005. Mouthpart-atlas of arctic sympagic amphipods — trophic niche separation based on mouthpart morphology and feeding ecology. Journal of Crustacean Biology 25(3): 401-412.

Ashelby CW, Page TJ, De Grave S, Hughes JM, Johnson ML. 2012. Regional scale speciation reveals multiple invasions of freshwater in Palaemoninae (Decapoda). Zoologica Scripta 41(3): 293-306.

Aucoin S, Himmelman JH. 2010. A first report on the shrimp Pontonia sp. and other potential symbionts in the mantle cavity of the penshell Pinna carnea in the Dominican Republic. Symbiosis 50: 135-141.

Bauer RT. 2004. Remarkable Shrimps: Adaptations and Natural History of the Carideans. Animal natural history series 7. Norman: University of Oklahoma Press.

434 Borradaile LA. 1915. Notes on Carides. The Annals and Magazine of Natural History 8(15): $205-213$.

435 Borradaile LA. 1917. On the structure and function of the mouth parts of palaemonid prawns. Proceedings of the Zoological Society of London 1917: 37-71.

437 Bracken HD, De Grave S, Felder DL. 2009. Phylogeny of the infraorder Caridea based on mitochondrial and nuclear genes (Crustacea: Decapoda). In: Martin JW, Crandall KA, Felder DL. (Eds) Decapod Crustacean Phylogenetics. Crustacean Issues Vol. 18: 281-305. Boca Raton: CRC Press.

Bruce AJ. 1967. Notes on some Indo-Pacific Pontoniinae III-IX. Descriptions of some new genera and species from the western Indian Ocean and the South China Sea. Zoologische Verhandelingen 87: $1-73$.

Bruce AJ. 1982. Papers from the Echinoderm Conference. 12. The shrimps associated with Indo-west Pacific echinoderms, with the description of a new species in the genus Periclimenes Costa, 1844 (Crustacea: Pontoniinae). Australian Museum Memoir 16: 191-216, 
447 Bruce AJ, Short JW. 1993. Leptopalaemon gagadjui gen. nov., sp. nov., a new freshwater palaemonid shrimp from Arnhem land, and a re-evaluation of Palaemonetes holthuisi Strenth, with the designation of a new genus, Calathaemon. Hydrobiologia 257: 73-94.

Burukovsky RN. 1986. Evolutionary aspects of trophic adaptation genesis in shrimps. In: Sokolova MN. (ed.). Feeding of marine invertebrates in natural conditions. 10-22. Shirshov Institute of Oceanology, Academy of Science of the USSR. Moscow: 1-114. (In Russian).

Caine EA. 1975. Feeding and masticatory structures of selected Anomura (Crustacea). Journal of Experimental Marine Biology and Ecology 18: 277-301.

Calman WT. 1907. On a freshwater decapod crustacean collected by W.J. Burchell at Pará in 1829. The Annals and Magazine of Natural History (7)19: 295-299.

Calman WT. 1909. On a blind prawn from the Sea of Galilee (Typhlocaris galilea g. et sp. n.). Transactions of the Linnean Society of London (2) Zoology 11: 93-97.

Caroli E. 1923. Di una specie italiana di Typhlocaris (T. salentina n. sp.) con osservazioni morofologiche e biologiche sul genere. Bolletino della Società di Naturalisti in Napoli 35: 265267.

Caroli E. 1924. Sulla presenza della Typhlocaris (T. salentina n. sp.) in terra d'Otranto. Contributo alla conoscenza del genere. Annuario del Museo Zoologico della R. Università di Napoli (Nuova Serie) 5: 1-20.

Casanova B, De Jong L, Moreau X. 2002. Carapace and mandibles ontogeny in the Dendrobranchiata (Decapoda), Euphausiacea, and Mysidacea (Crustacea): a phylogenetic interest. Canadian Journal of Zoology 80: 296-306.

Chace FA, Jr. 1992. On the classification of the Caridea (Decapoda). Crustaceana 63: 70-80.

Chace FA, Jr., Bruce AJ. 1993. The caridean shrimps (Crustacea: Decapoda) of the Albatross Philippine Expedition, 1907-1910, Part 6: Superfamily Palaemonoidea. Smithsonian Contributions to Zoology 543: 1-152.

Christoffersen ML. 1990. A new superfamily classification of the Caridea (Crustacea: Pleocyemata) based on phylogenetic pattern. Zeitschrift für Zoologische Systematik und Evolutionsforschung 28: 94-106. 
476 Coombs EF, Allen JA. 1978. The functional morphology of the feeding appendages and gut of Hippolyte varians (Crustacea: Natantia). Zoological Journal of the Linnean Society 64: 261-282.

478

479

480

481

482

483

484

485

486

487

488

489

490

491

492

493

494

495

496

497

498

499

500

501

502

503

Dana JD. 1852. Conspectus Crustaceorum \&c. Conspectus of the Crustacea of the Exploring Expedition under Capt. C. Wilkes, U.S.N. Macroura. Proceedings of the Academy of Natural Sciences of Philadelphia 1852: 10-29.

De Grave S. 2007. A new species of Euryrhynchus Miers, with a discussion of the systematic position of the Euryrhynchidae Holthuis (Crustacea, Decapoda). Zoologischer Anzeiger 246: 193-203.

De Grave S, Fransen CHJM. 2011. Carideorum catalogus: the recent species of the dendrobranchiate, stenopodidean, procarididean and caridean shrimps (Crustacea: Decapoda). Zoologische Mededilingen, Leiden 85(9): 195-589 figs 1-59.

De Grave S, Goulding LYD. 2011. Comparative morphology of the pereiopod 1 carpo-propodal (P1$\mathrm{CP}$ ) antennal flagellar grooming brush in caridean shrimps (Crustacea, Decapoda). Zoologischer Anzeiger 250: 280-301.

De Grave S, Ashelby CW. 2013. A re-appraisal of the systematic status of selected genera in Palaemoninae (Crustacea: Decapoda: Palaemonidae). Zootaxa 3734(3): 331-344.

De Haan W. 1833-1850. Crustacea. Pages i-xxxi, ix-xvi, 1-243 in PF. von Siebold, editor. Fauna Japonica sive Descriptio Animalium, quae in Itinere per Japoniam, Jussu et Auspiciis Superiorum, qui Summum in India Batava Imperium Tenent, Suspecto, Annis 1823-1830 Collegit, Notis, Observationibus et Adumbrationibus Illustravit, Lugduni-Batavorum, Plates A-J, L-Q, 1-55.

De Jong-Moreau L, Casanova B, Casanova J.-P. 2001. Detailed comparative morphology of the perioral structures of the Mysidacea and Euphausiacea (Crustacea): an indication for the food preference. Journal of the Marine Biological Association of the United Kingdom 81: 235-241.

Duriš Z, Horká I, Juračka PJ, Petrusek A, Sandford F. 2011. These squatters are not innocent: the evidence of parasitism in sponge-inhabiting shrimps. PLoS ONE 6(7): e21987.

Felgenhauer BE, Abele LG. 1983. Phylogenetic relationships among shrimp-like decapods. In: Schram FR. (Ed.), Crustacean Phylogeny Rotterdam. A.A. Balkema, pp. 291-311.

Felgenhauer BE, Abele LG. 1985. Feeding structures of two atyid shrimps, with comments on caridean phylogeny. Journal of Crustacean Biology 5(3): 397-419. 
505 Fransen CHJM. 2002. Taxonomy, phylogeny, historical biogeography, and historical ecology of the genus Pontonia Latreille (Crustacea, Decapoda, Caridea, Palaemonidae). Zoologische Verhandelingen, Leiden 336: 1-433, figures 1-257, plates 1-19.

Fransen CHJM. 2006. On Pontoniinae (Crustacea, Decapoda, Palaemonidae) collected from ascidians. Zoosystema 28(3): 713-746.

Fransen CHJM, De Grave S. 2009. Evolution and radiation of shrimp-like decapods: an overview. In: Martin JW, Crandall KA, Felder DL. (Eds.) Decapod Crustacean Phylogenetics. Crustacean Issues 18: 245-259.

Fujino T, Miyake S. 1968. On the mandible of the genus Palaemon of Japanese Palaemonid shrimps with discussion on its taxonomical value. Оһmu 1: 191-200.

Gan Z, Li X, Kou Q, Chan T-Y, Chu KH, Huang H. 2015. Systematic status of the caridean families Gnathophyllidae Dana and Hymenoceridae Ortmann (Crustacea: Decapoda): a further examination based on molecular and morphological data. Chinese Journal of Oceanology and Limnology 33: 149-158.

Garm A. 2004. Revising the definition of the crustacean seta and setal classification systems based on examinations of the mouthpart setae of seven species of decapods. Zoological Journal of the Linnean Society 142: 233-252.

Garm A, Høeg JT. 2001. Function and functional groupings of the complex mouth apparatus of the squat lobsters Munida sarsi Huus and M. tenuimana G.O. Sars (Crustacea: Decapoda). Biological Bulletin 200: 281-297.

Garm A, Hallberg E, Høeg JT. 2003. Role of maxilla 2 and its setae during feeding in the shrimp Palaemon adspersus (Crustacea: Decapoda). Biological Bulletin 204: 126-137.

Geiselbrecht H, Melzer RR. 2013. How do mandibles sense? - The sensory apparatus of larval mandibles in Palaemon elegans Rathke, 1837 (Decapoda, Palaemonidae). Arthropod Structure and Development 42(1): 1-16.

González-Ortegón E, Cuesta JA, Pascual E, Drake P. 2010. Assessment of the interaction between the white shrimp, Palaemon longirostris, and the exotic oriental shrimp, Palaemon macrodactylus, in a European estuary (SW Spain). Biological Invasions 12(6): 1731-1745. 
533 Guérin-Méneville FE. 1855-1856. Animales articulados con piés articulados. In: de la Sagra, R., Historia fisica politica y natural de la isla de Cuba. Segunda Parte. Historia Natural. Tomo VII (Crustaceos, Aragnides é Insectos) [1856]. Tomo VIII (Atlas de Zoologia) [1855]: i-xxxii, 1-371, Plates 1-20. Paris.

Heral M, Saudray Y. 1979. Regimes alimentaires et modifications des structures mandibulaires chez les larves, postlarves et adultes de Palaemonetes varians (Leach) (Decapoda, Palaemonidae) etudiees a l'aide du microscope electronique a balayage. Revue des Travaux de l'Institut des Peches Maritimes 43(4): 353-359.

Hobbs HH, Jr. 1991. A new generic assignment for a South American crayfish (Decapoda: Parastacidae) with revised diagnoses of the South American genera and comments on the Parastacid mandible. Proceedings of the Biological Society of Washington 104: 800-811.

Holthuis LB. 1951. A general revision of the Palaemonidae (Crustacea Decapoda Natantia) of the Americas. I. The subfamilies Euryrhynchinae and Pontoniinae. Allan Hancock Foundation Publications Occasional Papers 11: 1-332.

Holthuis LB. 1952. The Decapoda of the Siboga Expedition, Part XI: The Palaemonidae collected by the Siboga and Snellius Expeditions, with remarks on other species, part II: Subfamily Pontoniinae. Siboga-Expeditie Monographs 39a(10): 1-254.

Jayachandran KV, Joseph NI. 1989. Food and feeding habits of the slender river prawn, Macrobrachium idella (Hilgendorf, 1898) (Decapoda, Palaemonidae). Mahasagar 22: 121-129.

Kemp S. 1922. Notes on Crustacea Decapoda in the Indian Museum, XV. Pontoniinae. Records of the Indian Museum 24: 113-288

Kennedy H, Richardson CA, Duarte CM, Kennedy DP. 2001. Diet and association of Pontonia pinnophylax occurring in Pinna nobilis: insights from stable isotope analysis. Journal of the Marine Biological Association of the United Kingdom 81: 177-178.

Kensley B, Walker I. 1982. Palaemonid shrimps from the Amazon Basin, Brazil (Crustacea: Decapoda: Natantia). Smithsonian Contributions to Zoology 362: 1-28.

Li CP, De Grave S, Chan T-Y, Lei HC, Chu KH. 2011. Molecular systematics of caridean shrimps based on five nuclear genes: Implications for superfamily classification. Zoologischer Anzeiger 250(4): 270-279. 
562 Mantel SK, Dudgeon D. 2004. Dietary variation in a predatory shrimp Macrobrachium hainanense (Palaemonidae) in Hong Kong forest streams. Archiv für Hydrobiologie 160(3): 305-328.

564

565

566

567

568

569

570

571

572

573

574

575

576

577

578

579

580

581

582

583

584

585

586

587

588

589

Marin I, Anker A. 2008. A new species of Pontonia Latreille, 1829 (Crustacea, Decapoda, Palaemonidae) associated with sea squirts (Tunicata, Ascidiacea) from the Pacific coast of Panama. Zoosystema 30(2): 501-515.

Martin JW, Liu EM, Striley D. 2007. Morphological observations on the gills of dendrobranchiate shrimps. Zoologischer Anzeiger 246: 115-125.

Mekhanikova IV. 2010. Morphology of mandible and lateralia in six endemic amphipods (Amphipoda, Gammaridea) from Lake Baikal, in relation to feeding. Crustaceana 83(7): 865887.

Mekhanikova IV, Andreev DS, Belozerova OY, Mikhlin YL, Lipko SV, Klimenkov IV, Akimov VV, Kargin VF, Mazurova YV, Tauson VL, Likhoshway YV. 2012. Specific Features of Mandible Structure and Elemental Composition in the Polyphagous Amphipod Acanthogammarus grewingkii Endemic to Lake Baikal. PLoS ONE 7(8): 1-9. e43073.

Mielke W. 1984. Some Remarks on the Mandible of the Harpacticoida (Copepoda). Crustaceana 46(3): 257-260.

Miers EJ. 1877. On a collection of Crustacea, Decapoda and Isopoda, chiefly from South America, with descriptions of new genera and species. Proceedings of the Zoological Society of London 1877: 653-679.

Mitsuhashi M, Sin YW, Lei HC, Chan T-Y, Chu KH. 2007. Systematic status of the caridean families Gnathophyllidae Dana and Hymenoceridae Ortmann (Crustacea: Decapoda): a preliminary examination based on nuclear rDNA sequences. Invertebrate Systematics 21: 613-622.

Moore PG, Rainbow PS, Larson RJ. 1993. The mesopelagic shrimp Notostomus robustus Smith (Decapoda: Oplophoridae) observed in situ feeding on the medusan Atolla wyvillei Haeckel in the Northwest Atlantic, with notes on gut contents and mouthpart morphology. Journal of Crustacean Biology 13: 690-696.

Nobili G. 1904. Diagnoses préliminaires de vingt-huit espèces nouvelles de stomatopodes et décapodes macroures de la Mer Rouge. Bulletin du Muséum d'Histoire naturelle 10: 228-238. 
590 Olyslager NJ, Williams DD. 1993. Function of the type II microtrich sensilla on the lotic amphipod, 591 Gammarus pseudolimnaeus Bousfield. Hydrobiologia 259: 17-31.

592 Oshel PE, Steele VJ, Steele DH. 1988. Comparative SEM Morphology of Amphipod Microtrich Sensilla. Crustaceana Supplement No. 13, [Studies on Amphipoda (Proceedings of the VIth International Colloquium on Amphipod Crustaceans, Ambleteuse, France, 28 June-3 July 1985)]:

596 597 598 100-106.

Otto AW. 1828. Beschreibung einiger neuen, in den Jahren 1818 und 1819 im Mittelländischen Meere gefundener Crustaceen. Nova Acta Physico-Medica Academiae Caesareae Leopoldino-Carolinae Naturae Curiosorum (Verhandlungen der Kaiserlichen Leopoldinisch-Carolinischen Akademie der Naturforscher), Breslau \& Bonn 14: 331-354.

Parisi B. 1919. I decapodi Giapponesi del Museo di Milano. VII. Natantia. Atti della Società Italiana di Scienze naturali e del Museo Civico di Storia naturale di Milano 58: 59-99

Parisi B. 1921. Un nuovo crostaceo cavernicolo: Typhlocaris lethaea n. sp. Atti della Società Italiana di Scienze naturali e del Museo Civico di Storia naturale di Milano 59: 241-248.

Patwardhan SS. 1934. On the structure and mechanism of the gastric mill in Decapoda. V Caridea. Proceedings of the Indian Academy of Sciences (B) 1: 693-704.

Pohle G, Telford M. 1981. Morphology and classification of decapod crustacean larval setae: a scanning electron microscope study of Dissodactylus crinitichelis Moreira, 1901 (Brachyura: Pinnotheridae). Bulletin of Marine Science 31(3): 736-752.

Powell CB. 1977. A revision of the African freshwater shrimp genus Desmocaris Sollaud, with ecological notes and description of a new species (Crustacea Decapoda Palaemonidae). Revue de Zoologie Africaine 91(3): 649-674.

Rathbun MJ. 1902. Japanese stalk-eyed crustaceans. Proceedings of the United States National Museum 26: 23-55.

Rathke H. 1837. Zur Fauna der Krym. Ein Beitrag. Mémoires présentés à l'Académie Impériale des Sciences de St.Pétersbourg par divers Savants et lus dans ses Assemblées, series 6 B(3): 291-454. Richardson CA, Kennedy H, Duarte CM, Proud SV. 1997. The occurrence of Pontonia pinnophylax (Decapoda: Natantia: Pontoninae) in Pinna nobilis (Mollusca: Bivalvia: Pinnidae) from the 
618

619

620 Mediterranean. Journal of the Marine Biological Association of the United Kingdom 77: 12271230.

Richter S. 2004. A comparison of the mandibular gnathal edges in branchiopod crustaceans: implications for the phylogenetic position of the Laevicaudata. Zoomorphology 123: 31-44.

Risso A. 1816. Histoire Naturelle des Crustacés des Environs de Nice. Librairie Grecque-LatineAllemande, Paris.

Roberts MH. 1968. Functional morphology of the mouth-parts of the hermit crabs, Pagurus longicarpus and Pagurus pollicaris. Chesapeake Science 9: 9-20.

Schembri PJ. 1982. The functional morphology of the feeding and grooming appendages of Ebalia tuberosa (Pennant) (Crustacea: Decapoda: Leucosiidae). Journal of Natural History 16(4): 467480.

Schmitt WL. 1924. Report on the Macrura, Anomura and Stomatopoda collected by the BarbadosAntigua Expedition from the University of Iowa in 1918. University of Iowa Studies in Natural History 10: 65-99.

Short JW. 2004. A revision of Australian river prawns, Macrobrachium (Crustacea: Decapoda: Palaemonidae). Hydrobiologia 525: 1-100.

Short J, Humphrey C, Page T. 2013. Systematic revision and reappraisal of the Kakaducarididae Bruce (Crustacea: Decapoda: Caridea) with the description of three new species of Leptopalaemon Bruce \& Short. Invertebrate Systematics 27: 87-117.

Siegfried CA. 1982. Trophic relations of Crangon franciscorum Stimpson and Palaemon macrodactylus Rathbun - predation on the opossum shrimp, Neomysis mercedis Holmes. Hydrobiologia 89(2): 129-139.

Sitts RM, Knight AW. 1979. Predation by the estuarine shrimps Crangon franciscorum Stimpson and Palaemon macrodactylus Rathbun. Biological Bulletin 156: 356-368.

Sollaud E. 1911. Desmocaris trispinosus (= Paloemonetes trispinosus Aurivillius), type d'un nouveau genre, à nombreux charactères ancestraux de Décapodes palémonides. Comptes Rendus hebdomadaires des Séances de l'Académie des Sciences 152: 913-916.

Steele VJ, Oshel PE. 1987. The ultrastructure of an integumental mictrotrich sensillum in Gammarus setosus (Amphipoda). Journal of Crustacean Biology 7(1): 45-59. 
647 Storch V, Bluhm BA, Arntz WE. 2001. Microscopic anatomy and ultrastructure of the digestive system of three Antarctic shrimps (Crustacea: Decapoda: Caridea). Polar Biology 24: 604-614.

649

650

Strenth NE. 1976. A review of the systematics and zoogeography of the freshwater species of Palaemonetes Heller of North America (Crustacea: Decapoda). Smithsonian Contributions to Zoology 228: 1-27.

Thompson JR. 1967. Comments on phylogeny of section Caridea (Decapoda: Natantia) and the phylogenetic importance of the Oplophoroidea. Proceedings of Symposium on Crustacea - Part $1: 314-326$.

Tiefenbacher L. 1978. Zur Systematik und Verbreitung der Euryrhynchinae (Decapoda, Natantia, Palaemonidae). Crustaceana. 35: 177-189.

Tsurnamal M. 2008. A new species of the stygobiotic blind prawn Typhlocaris Calman, 1909 (Decapoda, Palaemonidae, Typhlocaridinae) from Israel. Crustaceana 81: 487-501.

Tziouveli V, Bastos-Gomez B, Bellwood O. 2011. Functional morphology of mouthparts and digestive system during larval development of the cleaner shrimp Lysmata amboinensis (de Man, 1888). Journal of Morphology 272: 1080-1091.

Walker I. 2009. Omnivory and resource-sharing in nutrient-deficient Rio Negro waters: Stabilization of biodiversity? Acta Amazonica 39(3): 617 - 626.

Watling L. 1989. A classification system for crustacean setae based on the homology concept. In: Felgenhauer B, Watling L, Thistle AB, eds. Functional morphology of feeding and grooming in Crustacea. Rotterdam: A.A. Balkema, 15-26.

Wheeler JFG, Brown FA. 1936. The periodic swarming of Anchistioides antiguensis (Schmitt) (Crustacea Decapoda) at Bermuda. Journal of the Linnean Society of London. Zoology 39: 413428.

Wickler W. 1973. Biology of Hymenocera picta Dana. Micronesica 9(2): 225-230.

Wong JCY, Williams DD. 2009. Comparison of the structure and presumptive function of Type II microtrichs and associated cuticular microstructures in species of Gammarus (Amphipoda, Crustacea) from different habitats. Zoomorphology 128(4): 315-325. 
674 Zimmer A, Araujo PB, Bond-Buckup G. 2009. Diversity and arrangement of the cuticular structures 675 of Hyallela (Crustacea: Amphipoda: Dogielinotidae) and their use in taxonomy. Zoologia 26(1): $676 \quad 127-142$.

677 


\section{Table 1 (on next page)}

Species examined in this study

Table 1: Species and accession numbers of specimens examined via SEM in this study. 
3 Species

Accession Number

4 Family Palaemonidae

5 Subfamily Palaemoninae

6 Palaemon macrodactylus Rathbun, 1902

OUMNH.ZC 2006-01-0039

7 Macrobrachium nipponense (De Haan, 1849)

OUMNH.ZC 2012-01-0060

8 Subfamily Pontoniinae

9 Pontonia pinnophylax (Otto, 1821)

OUMNH.ZC 2008-11-0081

10 Periclimenaeus caraibicus Holthuis, 1951

OUMNH.ZC 2009-01-0101

11 Gnathophyllidae

12 Gnathophyllum elegans (Risso, 1816)

OUMNH.ZC 2011-09-0005

13 Hymenoceridae

14 Hymenocera picta Dana, 1852

OUMNH.ZC 2010-04-0017

15 Desmocarididae

16 Desmocaris bislineata Powell, 1977

OUMNH.ZC 2009-19-0001

17 Euryrhynchidae

18 Euryrhynchus wrzesniowskii Miers, 1877

OUMNH.ZC 2006-21-0001

19 Anchistioididae

20 Anchistioides antiguensis (Schmitt, 1924)

OUMNH.ZC 2007-14-0001 
Table 2 (on next page)

Summary of the features of the mandibles examined in this study.

Table 2. Summary of the features of the mandibles examined in this study. $+=$ present, $-=$ absent, $v=$ vestigial. 


\begin{tabular}{llllll}
\cline { 3 - 5 } 3 & & Pars & Pars & Cuticular & Mandibular \\
4 & & molaris & incisivus & structures & palp \\
\cline { 2 - 5 } 5 & Palaemon macrodactylus & + & + & Type I & + \\
6 & Macrobrachium nipponense & + & + & Type I & + \\
7 & Pontonia pinnophylax & + & + & Type I & - \\
8 & Periclimenaeus caraibicus & + & + & Type II & - \\
9 & Gnathophyllum elegans & + & $+/ \mathrm{v}$ & Type III & - \\
10 & Hymenocera picta & + & - & Type IV & - \\
11 & Desmocaris bislineata & + & + & Type V & - \\
12 & Euryrhynchus wrzesniowskii & + & + & Type I & - \\
13 & Anchistioides antiguensis & + & + & - & -
\end{tabular}


Table 3 (on next page)

Details of the pars incisivus of each species examined.

Table 3. Details of the pars incisivus of each species examined. 


\begin{tabular}{|c|c|c|c|c|c|c|c|c|}
\hline & \multicolumn{4}{|l|}{ Right } & \multicolumn{4}{|l|}{ Left } \\
\hline & Form & $\begin{array}{l}\text { Anterior } \\
\text { margin }\end{array}$ & $\begin{array}{l}\text { Posterior } \\
\text { margin }\end{array}$ & Teeth & Form & $\begin{array}{l}\text { Anterior } \\
\text { margin }\end{array}$ & $\begin{array}{l}\text { Posterior } \\
\text { margin }\end{array}$ & Teeth \\
\hline Palaemon macrodactylus & $\begin{array}{l}\text { About twice as tall } \\
\text { as wide }\end{array}$ & $\begin{array}{l}\text { Strongly } \\
\text { convex }\end{array}$ & $\begin{array}{l}\text { Straight to } \\
\text { slightly concave }\end{array}$ & $\begin{array}{l}\text { 3, approximately } \\
\text { equal, widely-spaced, } \\
\text { triangular. }\end{array}$ & $\begin{array}{l}\text { About twice as tall } \\
\text { as wide }\end{array}$ & Strongly convex & $\begin{array}{l}\text { Straight to } \\
\text { slightly concave }\end{array}$ & $\begin{array}{l}\text { 4, widely-spaced, triangular, outer } \\
\text { teeth slightly larger than inner teeth. }\end{array}$ \\
\hline $\begin{array}{l}\text { Macrobrachium } \\
\text { nipponense } \\
\text { Fig. 2C }\end{array}$ & $\begin{array}{l}\text { Very broad, wider } \\
\text { than long in } \\
\text { middle portion }\end{array}$ & $\begin{array}{l}\text { Strongly } \\
\text { convex }\end{array}$ & Concave & $\begin{array}{l}\text { 3, approximately } \\
\text { equal, widely-spaced, } \\
\text { triangular. }\end{array}$ & $\begin{array}{l}\text { Very broad, wider } \\
\text { than long in middle } \\
\text { portion }\end{array}$ & Strongly convex & Straight & $\begin{array}{l}3 \text {, very robust, triangular, anterior } \\
\text { most tooth acute, remaining teeth } \\
\text { with rounded tip. }\end{array}$ \\
\hline $\begin{array}{l}\text { Pontonia pinnophylax } \\
\text { Figs. } 3 \mathrm{~A} \text { and } 3 \mathrm{C}\end{array}$ & $\begin{array}{l}\text { Elongate, slender, } \\
\text { equal in length to } \\
\text { pars molaris, } \\
\text { strongly curved } \\
\text { distally. }\end{array}$ & $\begin{array}{l}\text { Straight, } \\
\text { roughly } \\
\text { parallel with } \\
\text { posterior }\end{array}$ & $\begin{array}{l}\text { Straight, roughly } \\
\text { parallel with } \\
\text { anterior with } \\
\text { seven denticles }\end{array}$ & $\begin{array}{l}\text { 4, triangular, outer } \\
\text { teeth larger and } \\
\text { broader than inner } \\
\text { teeth. }\end{array}$ & $\begin{array}{l}\text { Elongate, slender, } \\
\text { equal in length to } \\
\text { pars molaris, } \\
\text { strongly curved } \\
\text { distally. }\end{array}$ & $\begin{array}{l}\text { Straight roughly } \\
\text { parallel with } \\
\text { posterior }\end{array}$ & $\begin{array}{l}\text { Straight, roughly } \\
\text { parallel with } \\
\text { anterior with five } \\
\text { denticles }\end{array}$ & $\begin{array}{l}5 \text {, triangular, acute, posterior-most the } \\
\text { largest, remaining teeth } \\
\text { approximately equal size. }\end{array}$ \\
\hline Periclimenaeus caraibicus & $\begin{array}{l}\text { Slender, ribbon- } \\
\text { like, slightly } \\
\text { twisted and } \\
\text { slightly shorter } \\
\text { than pars molaris }\end{array}$ & $\begin{array}{l}\text { Straight } \\
\text { roughly } \\
\text { parallel with } \\
\text { poserior }\end{array}$ & $\begin{array}{l}\text { Straight roughly } \\
\text { parallel with } \\
\text { anterior }\end{array}$ & $\begin{array}{l}\text { Distally damaged in } \\
\text { present specimen, } \\
\text { detail from Holthuis } \\
\text { (1951): Small acute } \\
\text { teeth present distally, } \\
\text { about } 10 \text { in number. }\end{array}$ & $\begin{array}{l}\text { Laminar in form, } \\
\text { slightly curved and } \\
\text { slightly shorter than } \\
\text { pars molaris. }\end{array}$ & Convex & Concave & $\begin{array}{l}\text { Distal margin broadly rounded, } \\
\text { tapering posteriorally, armed with } 11 \\
\text { small, acute teeth. }\end{array}$ \\
\hline $\begin{array}{l}\text { Gnathophyllum elegans } \\
\text { Fig. } 5 \mathrm{~A}\end{array}$ & Vestigial & - & - & - & Vestigial & - & - & - \\
\hline Hymenocera picta & Absent & - & - & - & Absent & - & - & - \\
\hline $\begin{array}{l}\text { Desmocaris bislineata } \\
\text { Fig. } 6 \mathrm{~A}\end{array}$ & $\begin{array}{l}\text { Slightly shorter } \\
\text { than pars molaris, } \\
\text { about } 3.5 \text { times as } \\
\text { long as wide, } \\
\text { slightly curved } \\
\text { inwards. }\end{array}$ & $\begin{array}{l}\text { Slightly } \\
\text { convex }\end{array}$ & Slightly concave & $\begin{array}{l}\text { 4, approximately } \\
\text { equal, widely-spaced, } \\
\text { triangular }\end{array}$ & $\begin{array}{l}\text { Similar to that of } \\
\text { the right mandible, } \\
\text { but slightly broader } \\
\text { in median part. }\end{array}$ & Slightly convex & Slightly concave & $\begin{array}{l}\text { 4, approximately equal, widely- } \\
\text { spaced, triangular }\end{array}$ \\
\hline $\begin{array}{l}\text { Euryrhynchus } \\
\text { wrzesniowskii }\end{array}$ & $\begin{array}{l}\text { Elongate, slender, } \\
\text { about } 3.5 \text { times as } \\
\text { long as wide, } \\
\text { parallel sided, } \\
\text { slightly curved } \\
\text { inwards. }\end{array}$ & $\begin{array}{l}\text { Straight } \\
\text { roughly } \\
\text { parallel with } \\
\text { poserior }\end{array}$ & $\begin{array}{l}\text { Straight roughly } \\
\text { parallel with } \\
\text { anterior }\end{array}$ & $\begin{array}{l}\text { 4, widely-spaced, } \\
\text { triangular, anterior- } \\
\text { most slightly larger } \\
\text { than remaining three. }\end{array}$ & Not Examined & - & - & - \\
\hline $\begin{array}{l}\text { Anchistioides antiguensis } \\
\text { Figs. } 7 \mathrm{D} \text { and } 7 \mathrm{~F}\end{array}$ & $\begin{array}{l}\text { Broad, about } 3 \\
\text { times as long as } \\
\text { wide, slightly } \\
\text { twisted. Equal to, } \\
\text { or slightly longer } \\
\text { than pars molaris. }\end{array}$ & $\begin{array}{l}\text { Slightly } \\
\text { convex }\end{array}$ & Slightly concave & $\begin{array}{l}\text { 3, widely-spaced, } \\
\text { triangular, acute, outer } \\
\text { two broader and longer } \\
\text { than median tooth. }\end{array}$ & $\begin{array}{l}\text { Broad, about } 3 \\
\text { times as long as } \\
\text { wide, slightly } \\
\text { twisted. Equal to, } \\
\text { or slightly longer } \\
\text { than pars molaris. }\end{array}$ & Strongly convex & $\begin{array}{l}\text { Straight to } \\
\text { slightly concave. }\end{array}$ & $\begin{array}{l}\text { 3, widely-spaced, triangular, acute, } \\
\text { teeth distally, outer two broader and } \\
\text { longer than the median tooth. }\end{array}$ \\
\hline
\end{tabular}


Table 4(on next page)

Details of the distal ends of the pars molaris of each species examined.

Table 4. Details of the distal ends of the pars molaris of each species examined. u.o.t. = upper outer tooth, u.i.t. = upper inner tooth, l.i.t. = lower inner tooth. 


\begin{tabular}{|c|c|c|}
\hline & Right & Left \\
\hline Palaemon macrodactylus & $\begin{array}{l}\text { Quadricuspid } \\
\text { (Fig. 1A) }\end{array}$ & $\begin{array}{l}\text { Quadricuspid } \\
\text { (Fig. 1E) }\end{array}$ \\
\hline Macrobrachium nipponense & $\begin{array}{l}\text { Quadricuspid } \\
\text { (Fig. 2A) }\end{array}$ & $\begin{array}{l}\text { Quadricuspid } \\
\text { (Figs. 2C-D) }\end{array}$ \\
\hline Pontonia pinnophylax & $\begin{array}{l}\text { Quadricuspid, } \\
\text { with deep concavity } \\
\text { (Fig. 3B) }\end{array}$ & $\begin{array}{l}\text { Quadricuspid, teeth } \\
\text { flattened } \\
\text { (Fig. 3C) }\end{array}$ \\
\hline Periclimenaeus caraibicus & $\begin{array}{l}\text { Bifid, } 2 \text { acute ridges } \\
\text { (Figs. 4A-B) }\end{array}$ & $\begin{array}{l}\text { Tricuspid } \\
\text { (Fig. 4C) }\end{array}$ \\
\hline Gnathophyllum elegans & $\begin{array}{l}\text { Single blade like tooth } \\
\text { (Fig. 5A) }\end{array}$ & $\begin{array}{l}\text { Single blade like tooth } \\
\text { (Fig. 5D) }\end{array}$ \\
\hline Hymenocera picta & $\begin{array}{l}2 \text { recurved, spine-like teeth } \\
\text { (Fig. } 4 \mathrm{E} \text { ) }\end{array}$ & $\begin{array}{l}2 \text { recurved, spine-like teeth } \\
\text { (Fig. 4F) }\end{array}$ \\
\hline Desmocaris bislineata & $\begin{array}{l}\text { Ridged } \\
\text { (Fig. 6B) }\end{array}$ & $\begin{array}{l}\text { Ridged } \\
\text { (Figs. 6D-F) }\end{array}$ \\
\hline Euryrhynchus wrzesniowskii & $\begin{array}{l}2 \text { lobate ridges } \\
\text { (Figs. 7A-B) }\end{array}$ & Not examined \\
\hline Anchistioides antiguensis & $\begin{array}{l}\text { Quadricuspid } \\
\text { (Fig. 7E) }\end{array}$ & $\begin{array}{l}\text { Tricuspid, u.o.t. and u.i.t. } \\
\text { fused, wing-like, 1.i.t. } \\
\text { bifid (Fig. 7F) }\end{array}$ \\
\hline
\end{tabular}


Table 5 (on next page)

Details of the mandibular cuticle structures of each species examined.

Table 5. Details of the mandibular cuticle structures of each species examined. u.o.t. = upper outer tooth, u.i.t. = upper inner tooth, I.o.t. = lower outer tooth, l.i.t. = lower inner tooth. 
4 Palaemon macrodactylus

Right

Left

5 Figs. 1B-C (Right)

Type I.

Type I

6 Fig. 1F (Left)

Well-developed, row

In three discrete regions: row along inner margin of along inner margin of l.i.t., 1.o.t, feebly developed small tuft on outer margin of row on u.o.t.

1.o.t., well-developed row on

outer margin between 1.o.t.

and u.o.t.

11 Macrobrachium nipponense Type I.

Type I.

12 Figs. 2A-B (Right)

Well-developed row

Well-developed row along

13 Fig. 2D (Left)

along inner margin of

inner margin of u.i.t. and as

1.o.t. and u.o.t.

a small tuft on the outer

margin between the 1.i.t. and

1.o.t.

17 Pontonia pinnophylax

Type I.

Type I.

18 Figs. 3B and 3F (Right)

Confined to the

Well-developed row, curled

19 Figs. 3D-E (Left)

concavity in pars

around outer and inner

molaris tip. Arranged

margin of u.i.t., between 1.i.t.

in a semicircle, in a

and 1.o.t. and along posterior

rosette-like fashion.

margin.

23 Periclimenaeus caraibicus

Type II.

Type II.

24 Fig. 4B (Right)

Present as a spine-like

Three distinct tufts one

25 Fig. 4C (Left)

tuft in position of u.o.t.

Gnathophyllum elegans

between u.i.t. and 1.i.t., and two on outer margin of 1.i.t.

28 Figs. 5A-C (Right)

29 Fig. 5D (Left)

Type III.

Very well-developed

consisting of a single

row that curls around to

As right mandible

cover the entirety of the 
distal surface.

33

34 Table 5. cont.

$35 \begin{array}{lll} & \text { Right } & \text { Left }\end{array}$

36 Hymenocera picta

Type IV.

As right mandible

37 Fig. 4E (Right)

Scattered

38 Fig. 4F (Left)

39 Desmocaris bislineata

Type V.

Type V.

40 Figs. 6B-C (Right)

Arranged into 12 equally Ridges broader than those

41 Figs. 6D-F (Left) spaced ridges giving a on right mandible, with

42 scalloped appearance. rounded tips.

Median ridges longest

44

and inner ridges notably

45 shorter than outer ridges.

46 Euryrhynchus wrzesniowskii Type I.

Not Examined

47 Figs. 7A-C (Right)

Arranged in a transverse

48

row.

49 Anchistioides antiguensis

Absent

Absent

50

51

52 


\section{1}

Palaemonidae: Palaemon macrodactylus

Figure 1. Palaemonidae (Palaemoninae): Palaemon macrodactylus, A) pars molaris of right mandible; B) Type I cuticular structures of right mandible; C) detail of Type I cuticular structures of right mandible; D) distally serrulate setae of mandible palp of right mandible; E) pars molaris of left mandible; F) lateral row of Type I cuticular structures of left mandible. Scale bars indicate $200 \mu \mathrm{m}$ (A), $100 \mu \mathrm{m}$ (E), $10 \mu \mathrm{m}$ ( $C$ and D) or $20 \mu \mathrm{m}$ (B and F). u.o.t. = upper outer tooth, u.i.t. $=$ upper inner tooth, l.o.t. = lower outer tooth, I.i.t. $=$ lower inner tooth. 
PeerJ Reviewing Manuscript
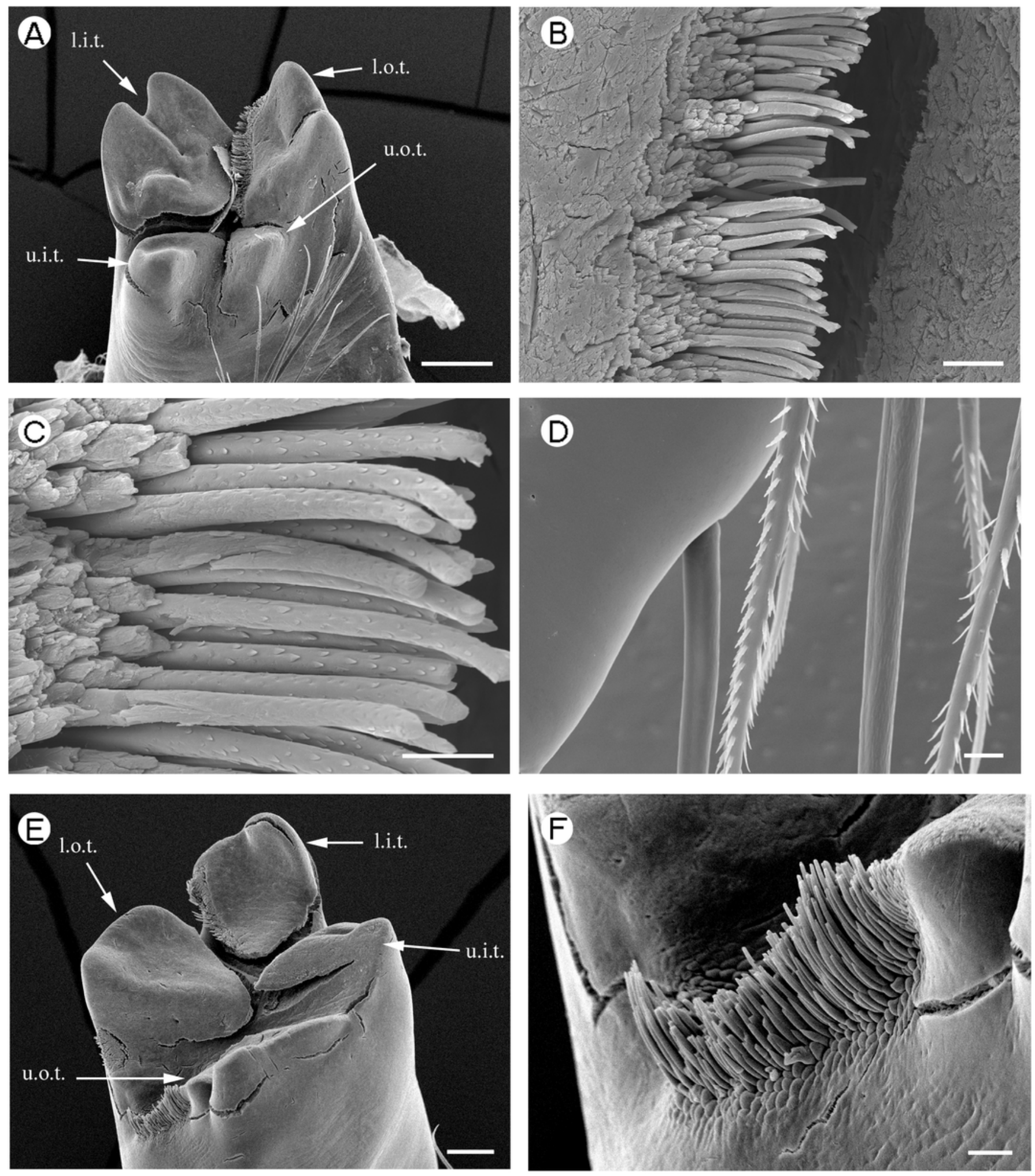
2

Palaemonidae: Macrobrachium nipponense

Figure 2. Palaemonidae (Palaemoninae): Macrobrachium nipponense, A) pars molaris of right mandible; B) Type I cuticular structures of right mandible; C) left mandible; D) pars molaris of left mandible. Scale bars indicate $500 \mu \mathrm{m}$ (C), $100 \mu \mathrm{m}$ (A and D) or $50 \mu \mathrm{m}$ (B). u.o.t. = upper outer tooth, u.i.t. = upper inner tooth, l.o.t. = lower outer tooth, l.i.t. = lower inner tooth.
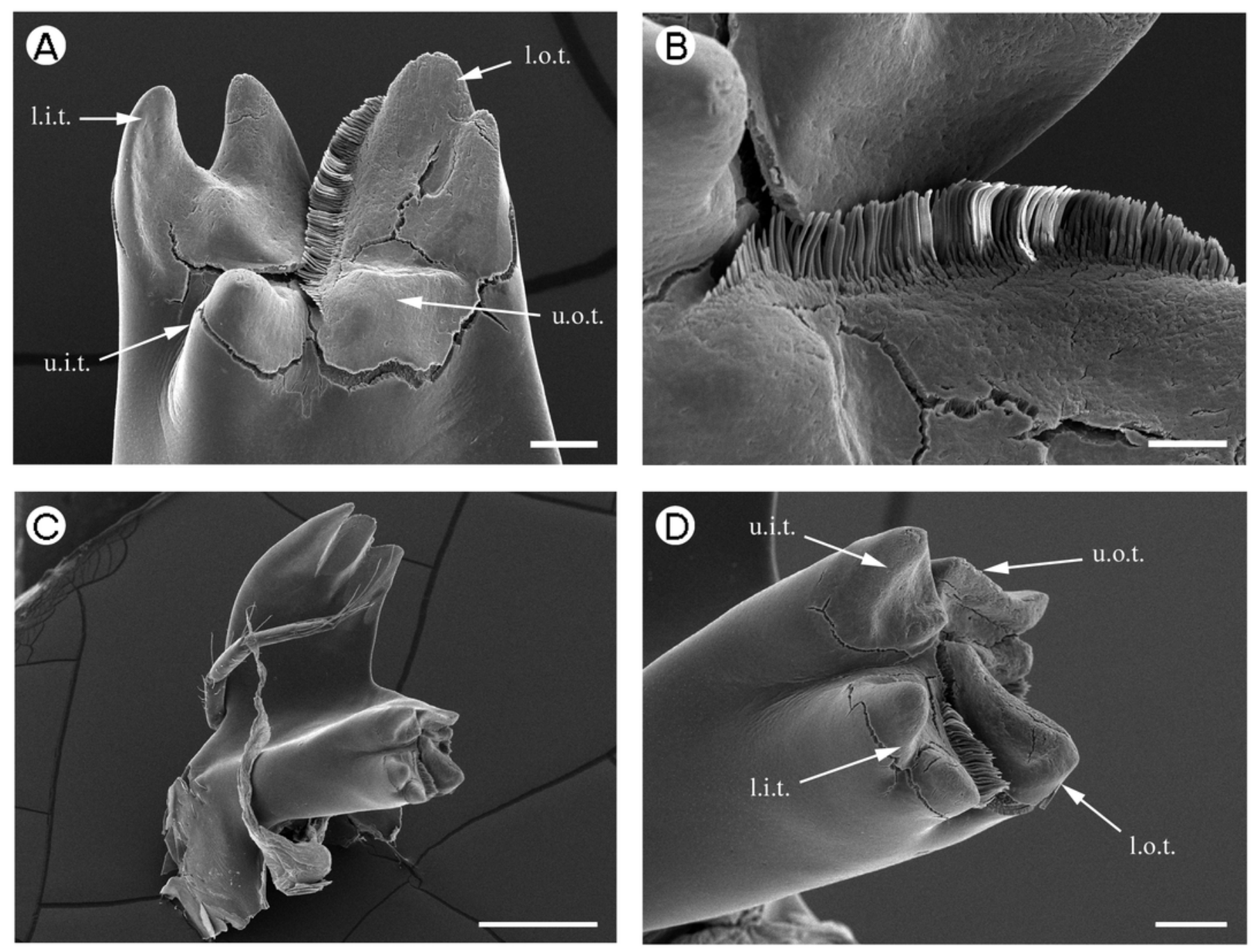
3

Palaemonidae: Pontonia pinnophylax

Figure 3. Palaemonidae (Pontoniinae): Pontonia pinnophylax, A) pars incisivus of right mandible (denticles indicated by white arrow); B) pars molaris of right mandible; C) pars incisivus of left mandible (denticles indicated by white arrow); D) pars molaris of left mandible; E) Type I cuticular structures of left mandible; F) Type I cuticular structures of right mandible. Scale bars indicate $100 \mu \mathrm{m}$ (B and D), $50 \mu \mathrm{m}$ (C) or $20 \mu \mathrm{m}$ (A, E and F). 

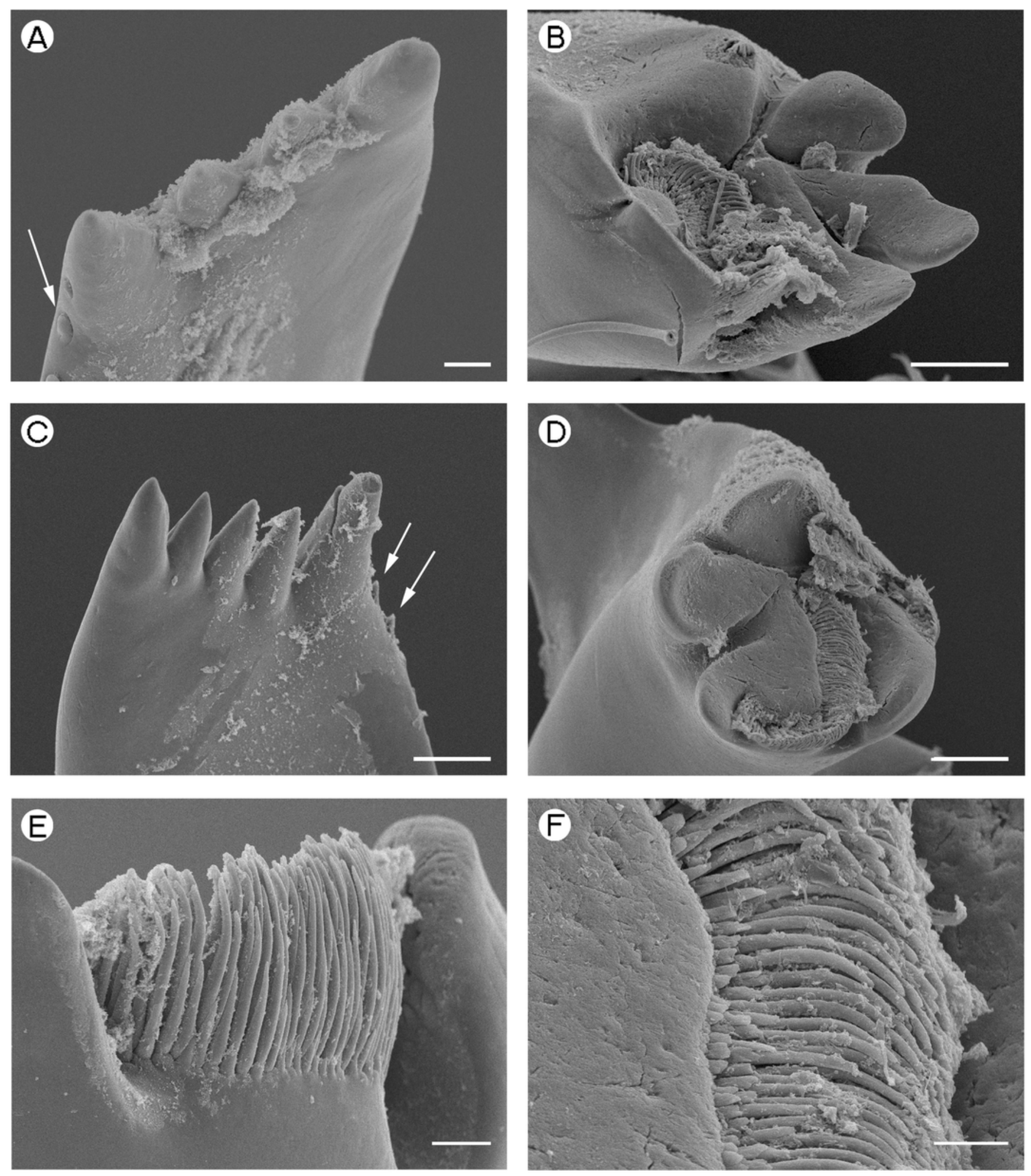


\section{4}

Palaemonidae: Periclimenaeus caraibicus and Hymenoceridae: Hymenocera picta

Figure 4. Palaemonidae (Pontoniinae): Periclimenaeus caraibicus, A) pars molaris of right mandible; B) pars molaris of right mandible (spine-like tuft of Type II cuticular structures indicated by white arrow); C) pars molaris of left mandible. Hymenoceridae: Hymenocera picta, D) right mandible; E) distal end of pars molaris of right mandible; F) distal end of pars molaris of left mandible. Scale bars indicate $20 \mu \mathrm{m}$ (A and B), $100 \mu \mathrm{m}$ (D), $50 \mu \mathrm{m}$ (C, E and F). 

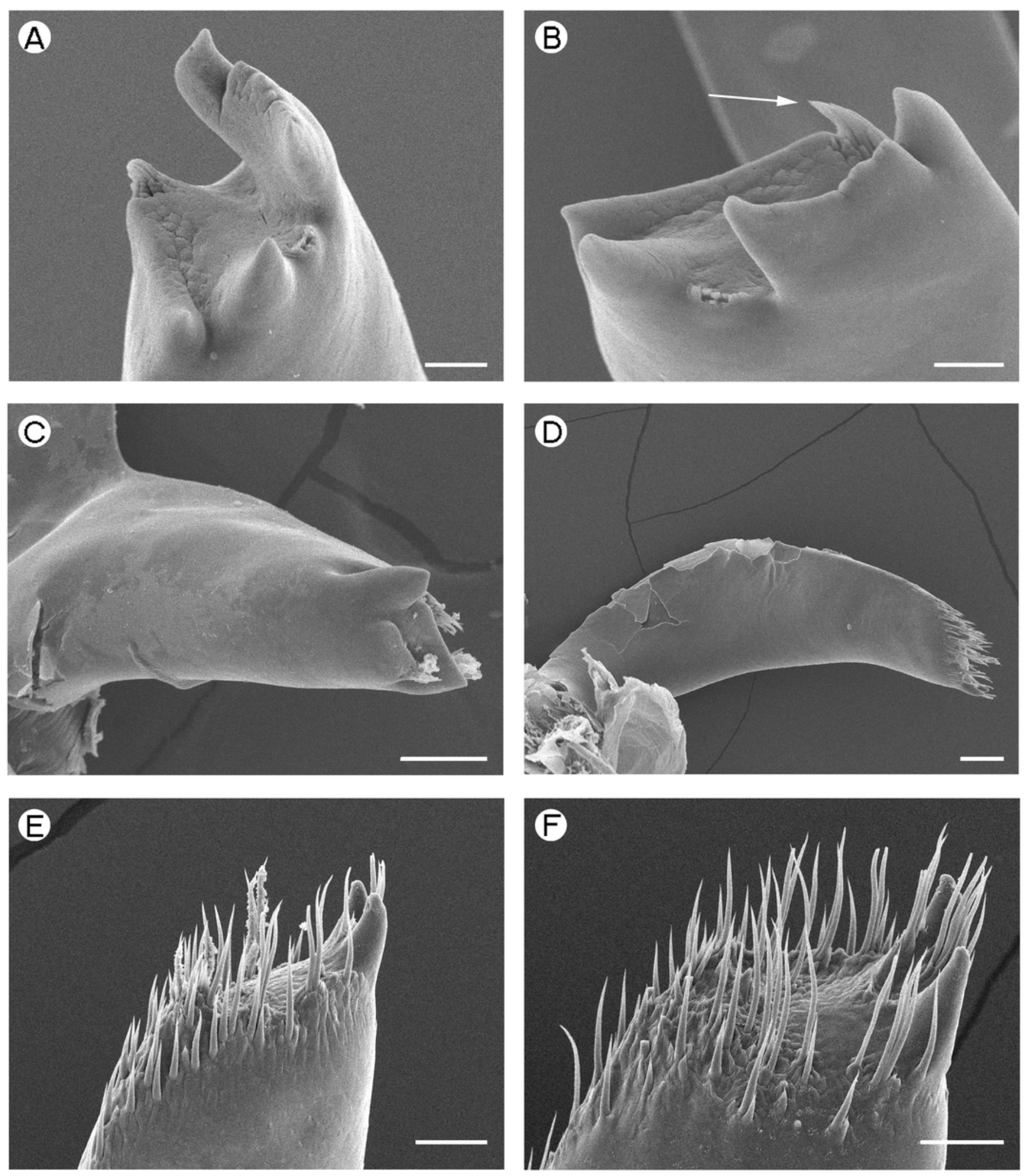


\section{5}

Gnathophyllidae: Gnathophyllum elegans

Figure 5. Gnathophyllidae: Gnathophyllum elegans, A) pars molaris of right mandible (vestigial pars incisivus indicated by white arrow); B) Type III cuticular structures of right mandible; C) detail of Type III cuticular structures of right mandible; D) pars molaris of left mandible. Scale bars indicate $20 \mu \mathrm{m}$ (B), $10 \mu \mathrm{m}$ (C), $100 \mu \mathrm{m}$ (A and D).
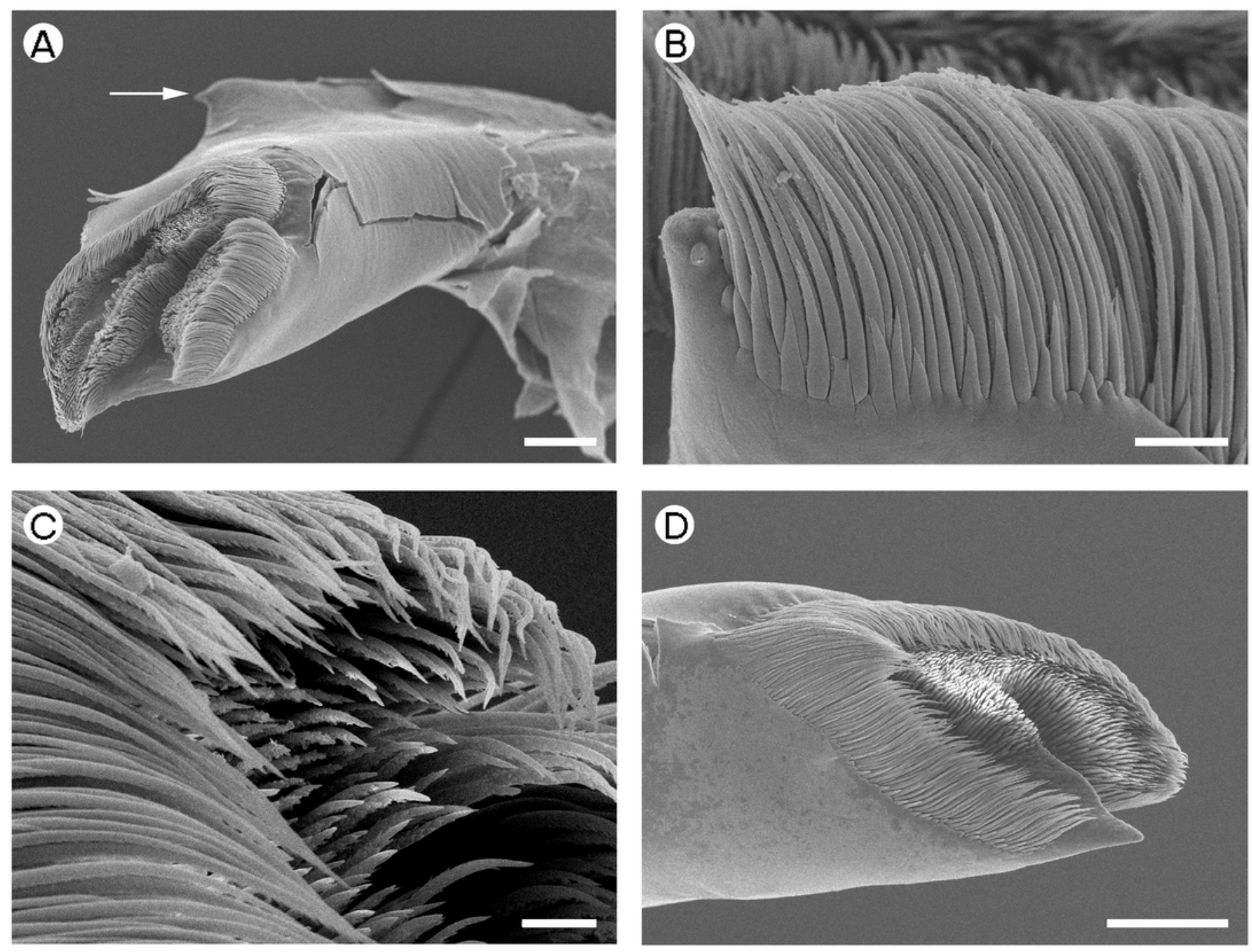
6

Desmocarididae: Desmocaris bislineata

Figure 6. Desmocarididae: Desmocaris bislineata, A) Right mandible; B) pars molaris of right mandible; C) detail of Type $\mathrm{V}$ cuticular structures of right mandible; D) pars molaris of left mandible; E) distal end of pars molaris of left mandible; F) distal end of pars molaris of left mandible. Scale bars indicate $100 \mu \mathrm{m}$ (A, B and D), $20 \mu \mathrm{m}$ (C), $50 \mu \mathrm{m}$ (E and F). 
PeerJ Reviewing Manuscript
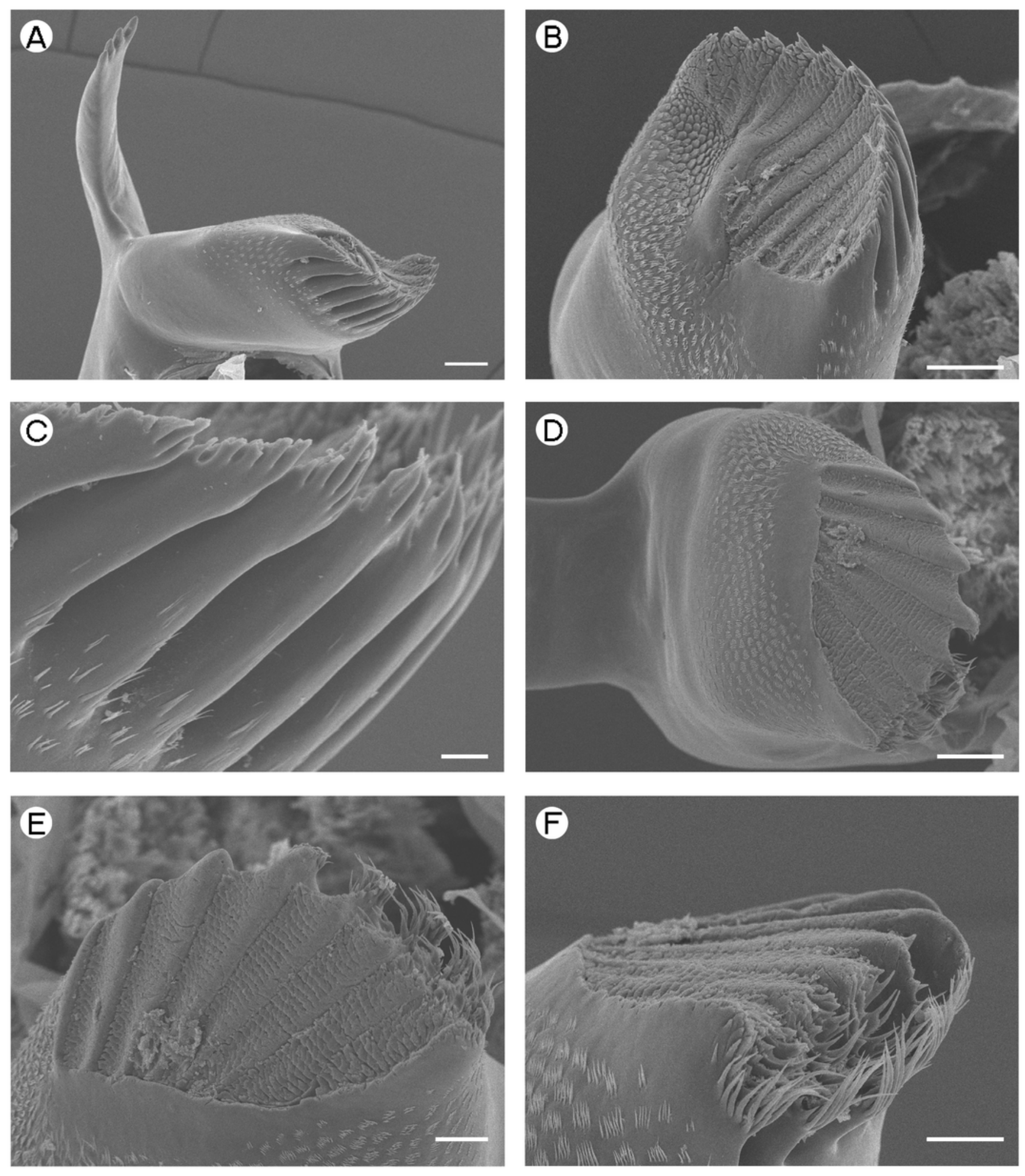


\section{7}

Euryrhynchidae: Euryrhynchus wrzesniowskii and Anchistioididae: Anchistioides antiguensis

Figure 7. Euryrhynchidae: Euryrhynchus wrzesniowskii, A) pars molaris of right mandible; B) pars molaris of right mandible; C) Type I cuticular structures of right mandible. Anchistioididae: Anchistioides antiguensis, D) right mandible; E) pars molaris of right mandible; F) left mandible. Scale bars indicate $10 \mu \mathrm{m}$ (C), $100 \mu \mathrm{m}$ (A, B, D, E and F). u.o.t. = upper outer tooth, u.i.t. $=$ upper inner tooth, I.o.t. $=$ lower outer tooth, I.i.t. $=$ lower inner tooth. 
PeerJ Reviewing Manuscript
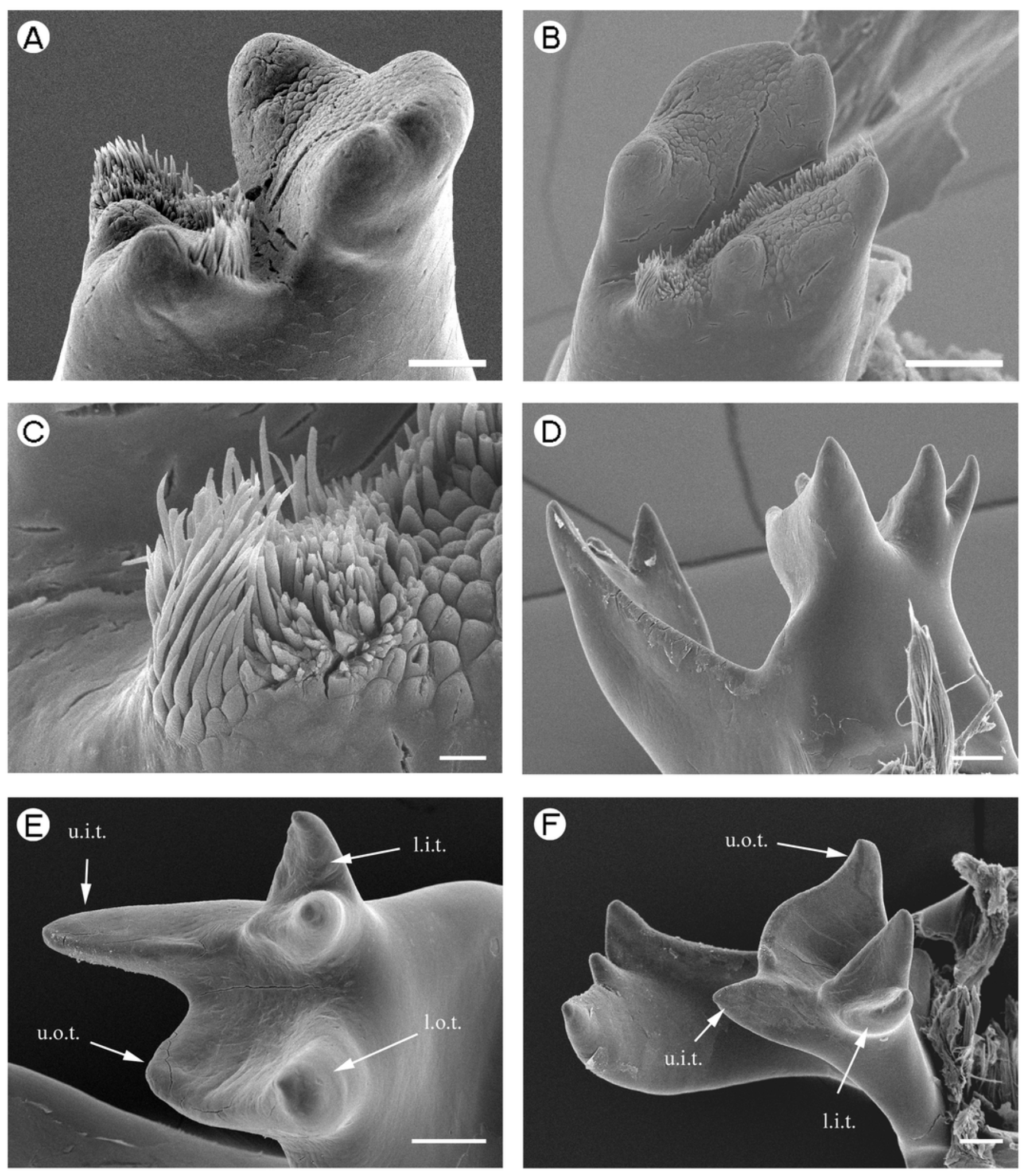